\title{
Design of Daily Hindu Prayer Applications Based on Telegram Bot
}

\author{
I Kadek Owen Nirvana Kaskora ${ }^{\mathrm{a} 1}$, Dr. I Made Sukarsa, ST., MT ${ }^{\mathrm{a} 2}$, Ni Made Ika Marini \\ Mandenni, ST., M.Kom ${ }^{3}$ \\ anformation Technology Study Program, Faculty of Engineering, Udayana University \\ Jimbaran Hill, Bali \\ e-mail: ${ }^{1}$ owen.nirvana98@gmail.com, ${ }^{2}$ sukarsa@unud.ac.id, ${ }^{3}$ made ikamarini@unud.ac.id
}

\begin{abstract}
Abstrak
Telegram Instant Messaging, diluncurkan pada Agustus 2013, adalah salah satu aplikasi IM yang Salah satu kelebihan dari telegram adalah mengolah pesan cepat dengan memberikan fitur bagi masyarakat luas untuk menggunakan Application Programming Interface. Bot merupakan salah satu API yang populer digunakan secara umum untuk menjalankan sebuah pekerjaan otomatis pada program komputer. Implementasi bot sudah mulai banyak digunakan. Salah satu kelebihan Bot adalah dapat memberikan data yang tidak dibatasi oleh waktu kepada pengguna. Sloka Bhagawad Gita dan doa Hindu dapat diakses melalui banyak media, namun tidak melalui pesan instan. Pengguna tetap harus membaca buku atau mencari di website untuk menemukan sloka atau doa. Salah satu solusinya adalah dengan menggunakan chat bot Telegram. Pengguna hanya perlu mengirimkan perintah untuk mencari informasi mengenai sloka atau doa hindu dalam chat bot tersebut, setelah itu maka bot akan merespon sesuai dengan perintah yang pengguna kirimkan. Bot akan mencari perintah tersebut pada database system dan mengirimkannya kepada pengguna. Bahasa pemrograman PHP atau Hypertext PreProcessor dengan framework laravel akan digunakan dalam membangun sistem ini.
\end{abstract}

Keywords: Application Programming Interface, Bot Telegram, Doa Hindu, Hypertext PreProcessor, Sloka Bhagawad Gita.

\section{Abstract}

Telegram Instant Messaging, launched in August 2013, is an IM application. One of the advantages of telegram is processing instant messages by providing features for the wider community to use the Application Programming Interface. Bot is one of the APIs used in general to run an automatic job on computer programs. The implementation of bots has begun to be widely used. One of the advantages of Bot is that it can provide data that does not manage time to users. Bhagawad Gita and Hindu prayers can be accessed through many media, but not through instant messages. Users should still read books or search on websites to find sloka or prayers. One solution is to use the Telegram chat bot. Users only need to send commands to find information about Hindu sloka or prayers in the chat bot, after which the bot will respond according to the instructions that the user sent. The bot will look for these commands on the database system and send them to the user. PHP programming language or Hypertext PreProcessor with the language framework that will be used in building this system.

Keywords : Application Programming Interface, Bhagawad Gita Sloka's, Hinduism Prayer, Hypertext PreProcessor language, Telegram Bot.

\section{Introduction}

According to Do and Gatica-Perez, smartphones are nowadays practical tools for daily activities (including social interactions). This is because smart phones can provide users with powerful services and resources through small media. Do and Gatica-Perez also mentioned that social interaction in communication is an important role in our daily life and a major part of our activities. According to Pinto, the messaging application claims to be able to cover some of the shortcomings in Whatsapp. As a messaging application, Telegram can provide users with 
convenient access because it is available on mobile and desktop platforms. Hamburg also added that Telegram is the fastest and safest instant messaging on the market.

Telegram Bot is a special Telegram account which is designed for automatic organization of messages so that they cannot be what the user is saying. Telegram users can be measured by Bot by sending command messages via private or group messages. The Telegram Bot account does not require an additional phone number to create an account. This account only functions as an interface for code running on the server.

As time goes by, daily prayers are increasingly being forgotten, even though they are very important when we start an activity. However, these prayers are still in book form and usually people will be lazy to carry books. Therefore, one solution is to create a chat bot which is useful for loading information about the prayer. The author here will conduct research on chat bots that are implemented in accordance with the above problems. The making of a Telegram chat bot containing prayer information is intended so that people can read prayers anywhere and anytime without having to carry books everywhere. In addition to searching for prayers, users can also add prayer suggestions in question. The addition of these suggestions is intended so that users can add useful critical input so that these prayers can be used and can be used in the future.

The source of Hindu religious teachings is the Vedic holy book which contains sacred teachings built by Hyang Widhi Wasa through the Rsi Agung. Bhagawad Gita is one of the holy books that is popular among the wider community because it contains new everyday human life. Therefore, the authors add the Sloka Bhagawad Gita list to the Telegram chatbot so that users can more easily learn and apply the knowledge gained from Bhagawad Gita.

\section{Research Method / Proposed Method}

The stages in this research in general can be seen in Figure 1. Figure 1 shows that the bot system will have 2 important components in order to run well and fulfill its objectives. The first component is a PHP script that runs the dashboard website where the admin updates the data on the database. The second component is a PHP script that aims to run a chatbot in order to receive commands from the user, which will be processed by the system and information about the prayer will come out according to the data in the database entered by the admin on the dashboard. In order for the bot to run properly, a good internet connection is needed. The internet is the link between all device components from the Bot side to the Telegram server.

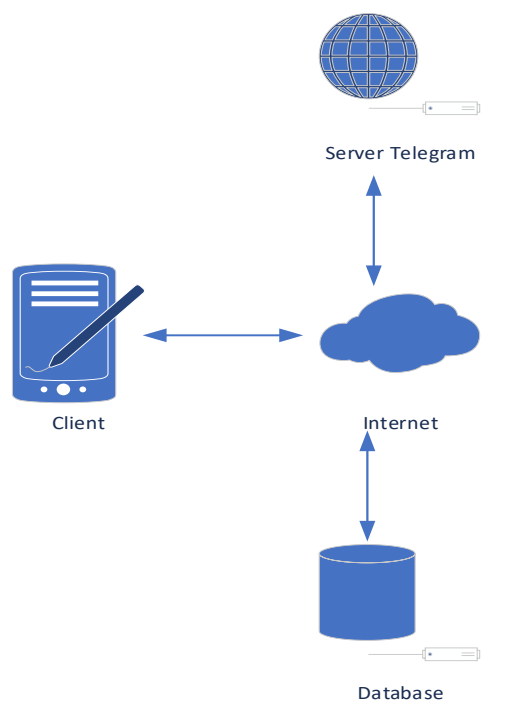

Figure 1. System Overview

\subsection{Database}

A database is a collection of tables that contain data and is a collection of fields and columns. The file structure that makes up the database is the Data Record and Field. Database is a set of data that is well integrated, usually a database consists of several tables in it. Database Management System (DBMS) is an application capable of managing database 
systems, Data Description Language (DDL), and Data Manipulating Languages (DML), which is the language used to describe data to the DBMS and provide facilities for change and maintenance.

\subsection{User Flowchart}

First the user enters input in the form of a prayer name to be searched for, then the bot will respond to the command and will search the Telegram bot server. If the prayer you are looking for is found in the database, the bot will display prayer data in the form of prayer titles, prayer contents, meanings, and voice or recorded examples in the form of audio files. If the prayer you are looking for is not in the database, the bot will display a message or notification "input is not available, please repeat".

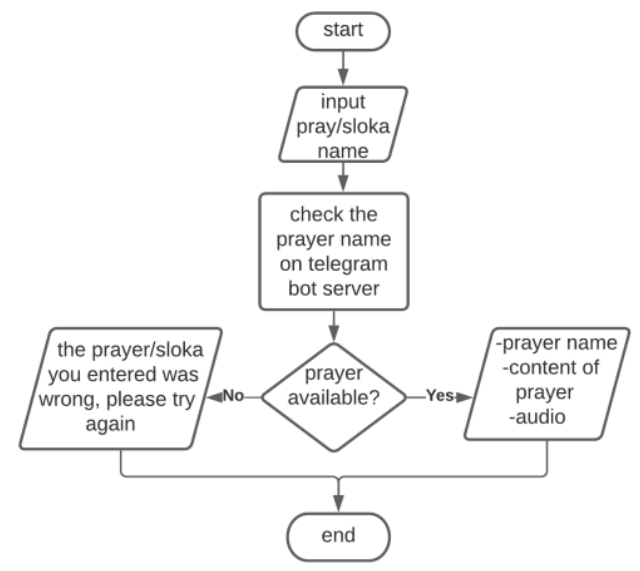

Figure 2. User Flowchart

\subsection{User Flowchart (Adding Suggestions)}

The chatbot also has a Suggestion feature, which is a feature that aims as a forum for user aspirations where they can provide input or criticism that aims to make the chatbot better in the future.

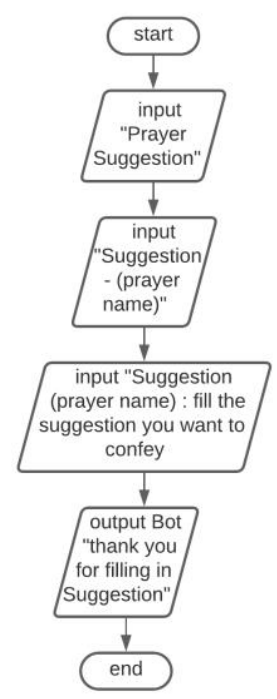

Figure 3. User Flowchart (Adding Suggestions)

\subsection{Admin Flowchart}

Before going to the admin dashboard, the admin is required to log in first. Then the admin can add prayer data through the admin dashboard. 


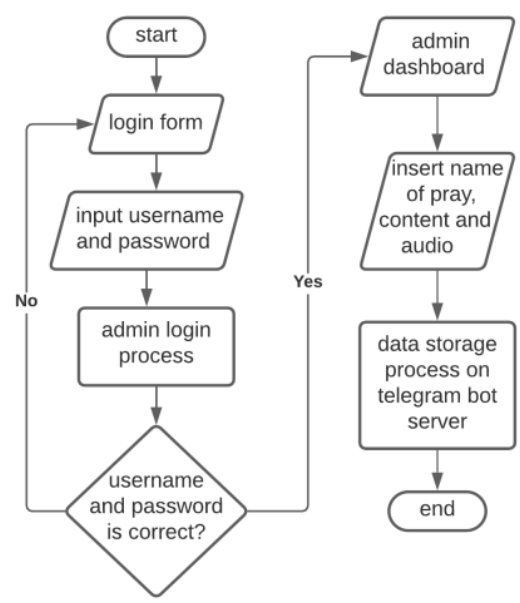

Figure 4. Admin Flowchart

\subsection{Use Case Diagram}

The Use Case Diagram shows that the admin can do 3 activities, namely adding prayer data, editing prayer data, and viewing prayer data, while users can only do 2 activities, namely viewing prayer data and looking for prayer data on the Telegram chat bot.

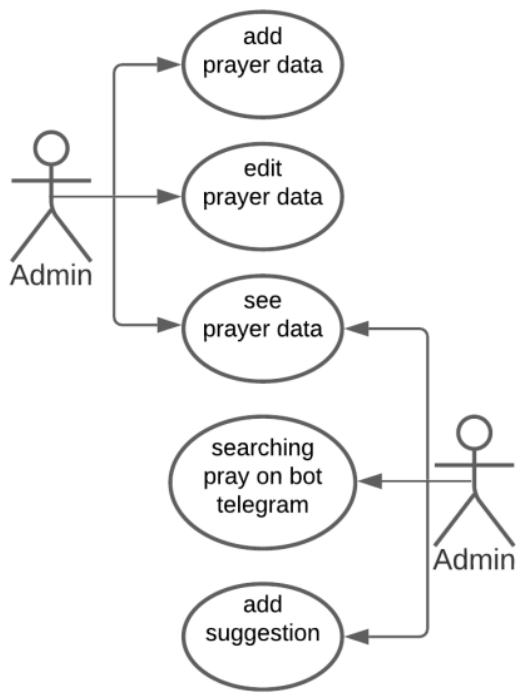

Figure 5. Use Case Diagram

\subsection{Database}

The database between the website and the Telegram bot is put together, in the database there are several tables that store admin data and prayer data. The database used in the Design of Daily Hindu Prayer Applications based on Telegram Bot is named prayer_hindu. PDM (Physical Data Model) from the prayer_hindu database design has 6 tables, namely the pray table, sloka table, suggestion table, user table, inbox table, and outbox table. 

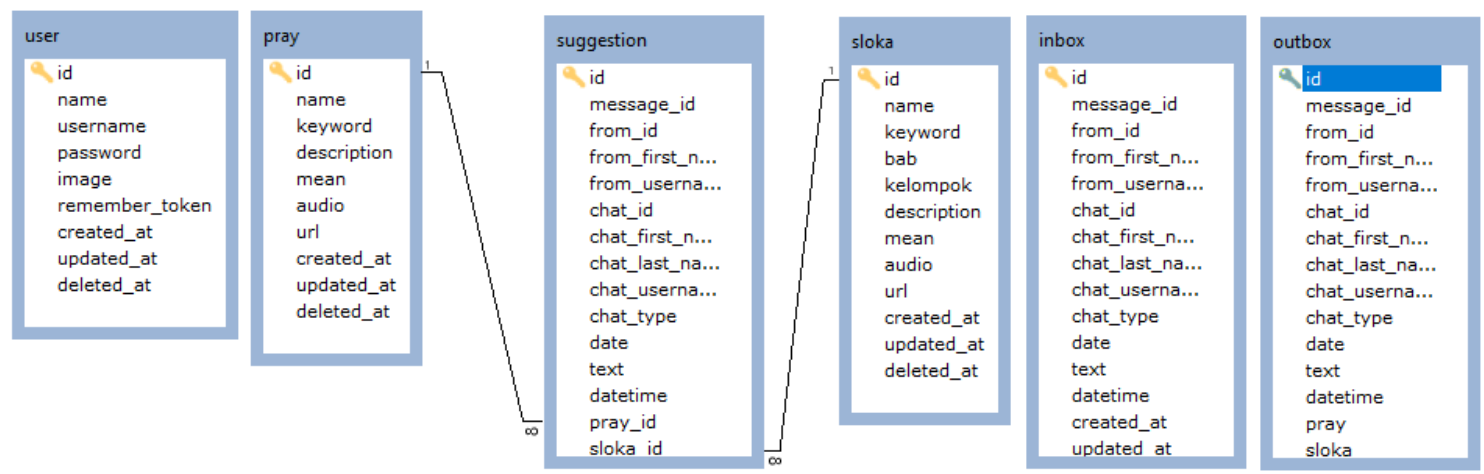

Figure 6. Physical Data Model

\section{Literature Study}

The Literature Study discusses materials related to the Design of Sloka Application and Daily Hindu Prayers Based on Telegram Bot.

\subsection{Daily Prayers according to Hinduism}

Prayer is one of the elements of belief that has a very important position and has enormous uses and benefits, especially in ethical, moral and spiritual development. Therefore, prayers must be believed and uttered or delivered with holiness and sincerity to Sang Hyang Widhi Wasa (God Almighty), as worship and praise in order to achieve a goal expected in this life.

\subsection{Bhagawad Gita}

Bhagawadgita (Sanskrit: भगवद् गीता; Bhagavad-gītā) is a part of the famous Mahabharata, in the form of dialogue set out in verse. In this dialogue, Lord Krishna, the Personality of Godhead is the main speaker expounding the teachings of Vedanta philosophy, while Arjuna, Lord Krishna's direct disciple is the listener. The literal meaning of Bhagavad-gita is "Chanting of Lord Bhagavan (Bhaga = perfect excellence, van = possessing, Bhagavan = Who has perfect excellence, perfect beauty, infinite wealth, eternal fame, unlimited power, infinite intelligence and complete detachment, shared at the same time).

\subsection{Telegram}

Telegram is an instant messaging application that focuses on speed and security. According to Pinto (2014) Telegram, as an instant messaging application, claims to cover some of the shortcomings that exist in Whatsapp. Users can use Telegram on all devices simultaneously and messages will be synchronized on their mobile, tablet or desktop device.

\section{Result and Discussion}

The test was carried out on the website as an admin dashboard test and the Telegram application as a Telegram Bot test.

\subsection{Telegram Bot}

The Telegram bot here will display information about the prayers that match the database prayer_hindu. The Telegram bot here has several features such as searching for prayers according to the name of the prayer, displaying a prayer list and also we can find information about prayers using the buttons provided by the bot.

\subsection{Display When Searching According to Prayer Name}

When you want to find a prayer, users are required to enter the name of the prayer on the Telegram chatbot. This is done so that the bot can search the database according to the prayer name entered. Figure 9 shows the prayer that is sought named/ prayer_megetting_food or prayer finished eating and when the user searches using the name of the prayer, the contents of the prayer, the meaning of the prayer and the audio of the prayer will appear. 


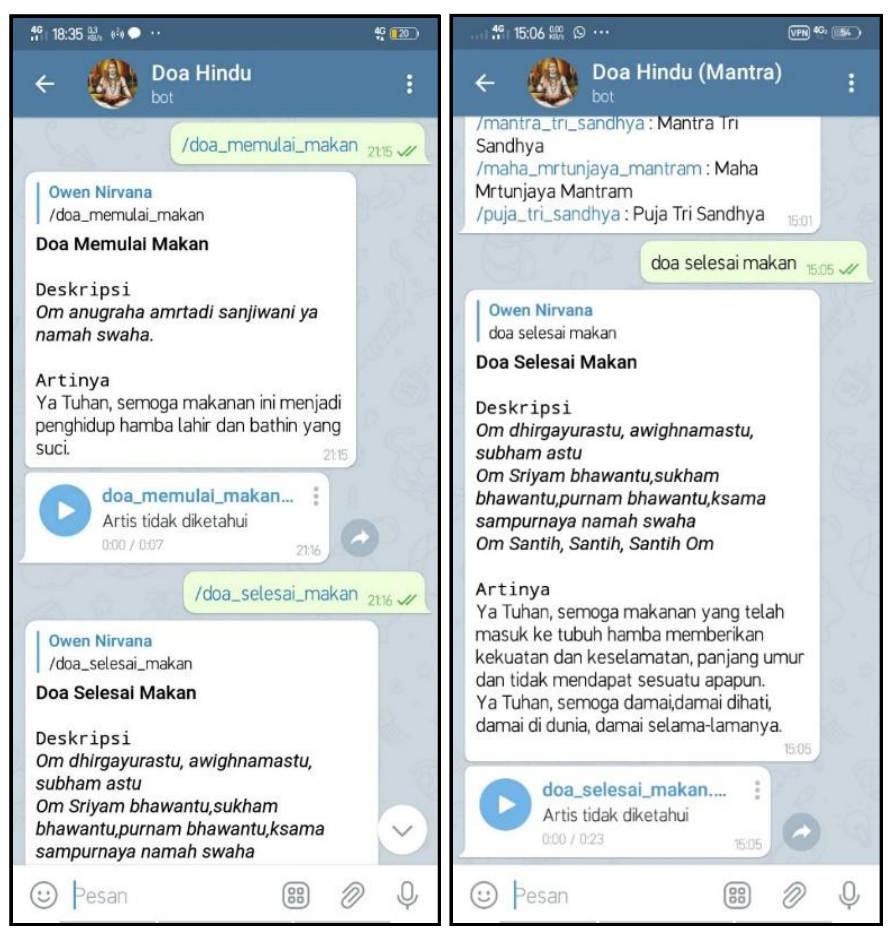

Figure 7. Searching according to the Prayer's Name

\subsection{UAT Result Analysis}

UAT (User Acceptance Testing) is a test carried out by end-users where the user will fill out a questionnaire based on the experience gained while trying the chatbot. The user referred to here is a combination of the general public ranging from students, students, employees to customary stakeholders. Each question from the questionnaire is to show the level of usability according to user acceptance. The questions given in this questionnaire can be seen in Table 4.3. The aspects of usability testing include five things, namely

1. Learnability, shows how easy it is for users to complete basic tasks when viewing or processing an existing system for the first timeEfficiency, describes how quickly users can complete existing tasks when they first learn about the system.

2. Memorability, describes how easy it is for users to put the system to good use after a while of non-use.

3. Errors, describes errors that users might make and how easy it is for them to troubleshoot.

4. Satisfaction, explain the level of user satisfaction of the system created.

The questionnaire was distributed to students, students, employees, and also customary stakeholders, a total of 35 respondents.

Table 1. A list of questions

\begin{tabular}{|c|c|c|c|c|c|}
\hline \multirow[t]{2}{*}{ No } & \multirow[t]{2}{*}{ Question } & \multicolumn{4}{|c|}{ Usability Aspects } \\
\hline & & VG & G & PG & NG \\
\hline \multicolumn{6}{|c|}{ System Aspects } \\
\hline 1 & Is Telegram interface easy to use? & 23 & 12 & 0 & 0 \\
\hline 2 & $\begin{array}{l}\text { Does the feature of a button on the Telegram chatbot make it } \\
\text { easier to search for Hindu verses or prayers? }\end{array}$ & 6 & 28 & 0 & 0 \\
\hline 3 & $\begin{array}{l}\text { Can the voice media in the Telegram chatbot help you recite } \\
\text { hindu sloka or prayers? }\end{array}$ & 15 & 20 & 0 & 0 \\
\hline \multicolumn{6}{|c|}{ User Aspects } \\
\hline 1 & $\begin{array}{l}\text { Do you find it helpful to use the Telegram chatbot as a means of } \\
\text { accessing Hindu sloka and prayers? }\end{array}$ & 26 & 9 & 0 & 0 \\
\hline
\end{tabular}




\begin{tabular}{llllll}
\hline 2 & $\begin{array}{l}\text { Does the Telegram chatbot make it easy to find Hindu sloka and } \\
\text { prayers? }\end{array}$ & 25 & 0 & 0 \\
\hline 3 & $\begin{array}{l}\text { In your opinion, is the Telegram chatbot more practical as a } \\
\text { medium for finding Hindu sloka and prayers? }\end{array}$ & 13 & 0 & 0 \\
\hline 4 & $\begin{array}{l}\text { When carrying out certain activities, can the use of the Telegram } \\
\text { chatbot replace other media (books or Android applications) as } \\
\text { a medium for searching for Hindu poetry and prayers? }\end{array}$ & 15 & 1 & 0 \\
\hline 5 & $\begin{array}{l}\text { After using the Telegram chatbot, is the delivery of Hindu poetry } \\
\text { and prayers quickly conveyed to you? }\end{array}$ & 16 & 18 & 1 & 0 \\
\hline $6 \quad \begin{array}{l}\text { What do you think about the appropriateness of using the } \\
\text { Telegram chatbot to provide information about the media for } \\
\text { searching for Hindu sloka and prayers? }\end{array}$ & 22 & 0 & 0 \\
\hline Interaction Aspects & & & \\
\hline $1 \quad \begin{array}{l}\text { Through the Telegram chatbot, users can provide suggestions } \\
\text { aimed at developing and evaluating prayers. In your opinion, } \\
\text { does this feature make it easy to contact related parties if there } \\
\text { is an error in the prayer in question? }\end{array}$ & 20 & 2 & 0 \\
\hline
\end{tabular}

Table 2. List of Respondents' Answers

\begin{tabular}{|c|c|c|c|c|c|c|c|c|c|}
\hline \multirow{2}{*}{ No } & \multirow[t]{2}{*}{ Question } & \multicolumn{4}{|c|}{ Usability Aspects } & \multicolumn{4}{|c|}{ Percentage } \\
\hline & & VG & G & PG & NG & VG & G & PG & NG \\
\hline \multicolumn{10}{|c|}{ System Aspects } \\
\hline 1 & Is Telegram interface easy to use? & 23 & 12 & 0 & 0 & $\begin{array}{l}66 \\
\%\end{array}$ & $\begin{array}{l}34 \\
\%\end{array}$ & $0 \%$ & $0 \%$ \\
\hline 2 & $\begin{array}{l}\text { Does the feature of a button on the } \\
\text { Telegram chatbot make it easier to } \\
\text { search for Hindu verses or prayers? }\end{array}$ & 6 & 28 & 0 & 0 & $\begin{array}{l}17 \\
\%\end{array}$ & $\begin{array}{l}73 \\
\%\end{array}$ & $0 \%$ & $0 \%$ \\
\hline 3 & $\begin{array}{l}\text { Can the voice media in the Telegram } \\
\text { chatbot help you recite hindu sloka or } \\
\text { prayers? }\end{array}$ & 15 & 20 & 0 & 0 & $\begin{array}{l}43 \\
\%\end{array}$ & $\begin{array}{l}57 \\
\%\end{array}$ & $0 \%$ & $0 \%$ \\
\hline \multicolumn{10}{|c|}{ User Aspects } \\
\hline 1 & $\begin{array}{l}\text { Do you find it helpful to use the } \\
\text { Telegram chatbot as a means of } \\
\text { accessing Hindu sloka and prayers? }\end{array}$ & 26 & 9 & 0 & 0 & $\begin{array}{l}74 \\
\%\end{array}$ & $\begin{array}{l}26 \\
\%\end{array}$ & $0 \%$ & $0 \%$ \\
\hline 2 & $\begin{array}{l}\text { Does the Telegram chatbot make it } \\
\text { easy to find Hindu sloka and prayers? }\end{array}$ & 10 & 25 & 0 & 0 & $\begin{array}{l}29 \\
\%\end{array}$ & $\begin{array}{l}71 \\
\% \\
\end{array}$ & $0 \%$ & $0 \%$ \\
\hline 3 & $\begin{array}{l}\text { In your opinion, is the Telegram chatbot } \\
\text { more practical as a medium for finding } \\
\text { Hindu sloka and prayers? }\end{array}$ & 13 & 22 & 0 & 0 & $\begin{array}{l}37 \\
\%\end{array}$ & $\begin{array}{l}63 \\
\%\end{array}$ & $0 \%$ & $0 \%$ \\
\hline 4 & $\begin{array}{l}\text { When carrying out certain activities, can } \\
\text { the use of the Telegram chatbot replace } \\
\text { other media (books or Android } \\
\text { applications) as a medium for } \\
\text { searching for Hindu poetry and } \\
\text { prayers? }\end{array}$ & 15 & 19 & 1 & 0 & $\begin{array}{l}43 \\
\%\end{array}$ & $\begin{array}{l}54 \\
\%\end{array}$ & $3 \%$ & $0 \%$ \\
\hline 5 & $\begin{array}{l}\text { After using the Telegram chatbot, is the } \\
\text { delivery of Hindu poetry and prayers } \\
\text { quickly conveyed to you? }\end{array}$ & 16 & 18 & 1 & 0 & $\begin{array}{l}46 \\
\%\end{array}$ & $\begin{array}{l}51 \\
\%\end{array}$ & $3 \%$ & $0 \%$ \\
\hline 6 & $\begin{array}{l}\text { What do you think about the } \\
\text { appropriateness of using the Telegram } \\
\text { chatbot to provide information about the } \\
\text { media for searching for Hindu sloka } \\
\text { and prayers? }\end{array}$ & 13 & 22 & 0 & 0 & $\begin{array}{l}37 \\
\%\end{array}$ & $\begin{array}{l}63 \\
\%\end{array}$ & $0 \%$ & $0 \%$ \\
\hline \multicolumn{10}{|c|}{ Interaction Aspects } \\
\hline 1 & Through the Telegram chatbot, users & 8 & 20 & 2 & 0 & 23 & 71 & $6 \%$ & $0 \%$ \\
\hline
\end{tabular}


can provide suggestions aimed at developing and evaluating prayers. In your opinion, does this feature make it easy to contact related parties if there is an error in the prayer in question?

The percentage is obtained from the results of the respondent's answer / number of respondents then multiplied by 100 , for example, in the first question, which is 23 in the SB's answer, so that $(23 / 35) \times 100 \%=66 \%$ is obtained.

The data obtained in Table 2 is then processed by multiplying each answer point by the weight that has been determined according to the weight table of the answer value. The weights of each category are in Table 3.

Table 3. List of Weighted Answers

\begin{tabular}{lll}
\hline Code & Answer Description & Weight \\
\hline VG & Very Good & 4 \\
\hline$G$ & Good & 3 \\
\hline PG & Pretty Good & 2 \\
\hline NG & Not Good & 1 \\
\hline
\end{tabular}

The results of the calculation by multiplying each predetermined weight answer, the results are as shown in Table 4 as follows:

Table 4. UAT Value Calculation

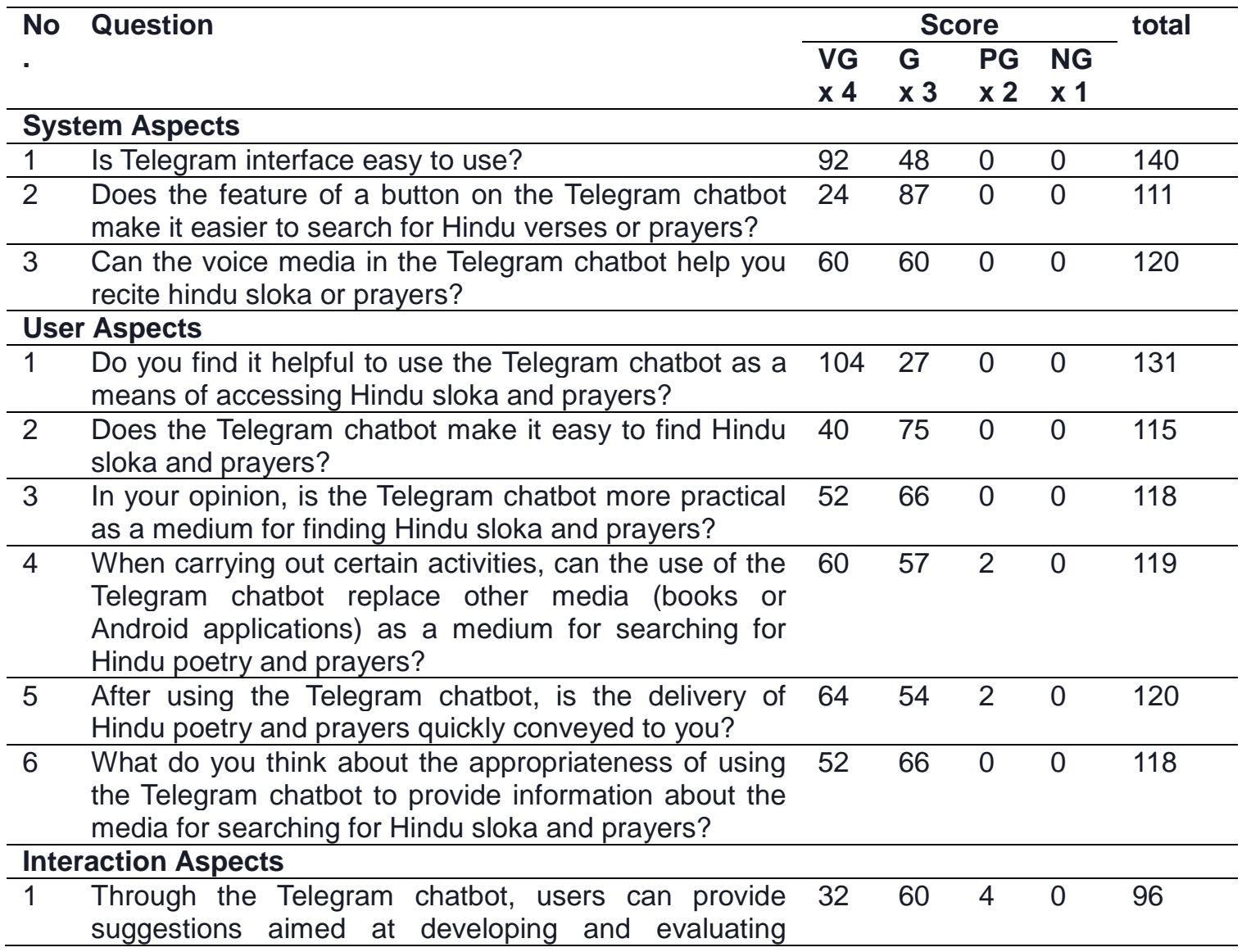


prayers. In your opinion, does this feature make it easy

to contact related parties if there is an error in the prayer in question?

\section{Results Analysis}

a. Analysis of the first question, from the table above it can be seen that the total value of 35 respondents for the first question is 140 . The average score is $140 / 35=4$. The percentage of the value is $4 / 4 \times 100=100 \%$.

b. Analysis of the first question, from the table above it can be seen that the total value of 35 respondents for the second question is 111 . The average score is $111 / 35=3.1714$. The percentage of value is 3.1714 / $4 \times 100=79.3 \%$

c. Analysis of the first question, from the table above it can be seen that the total value of 35 respondents for the third question is 120 . The average score is $120 / 35=3.4285$. The percentage of value is $3.4385 / 4 \times 100=85.7 \%$.

d. Analysis of the first question, from the table above it can be seen that the total score of 35 respondents for the fourth question was 131 . The average score was $131 / 35=$ 3.7428. The percentage of value is $3.7428 / 4 \times 100=93.5 \%$.

e. Analysis of the first question, from the table above it can be seen that the total value of 35 respondents for the fifth question is 115 . The average score is $115 / 35=3.2875$. the percentage value is $3.2875 / 4 \times 100=82.1 \%$.

f. Analysis of the first question, from the table above it can be seen that the total value of 35 respondents for the sixth question is 118 . The average score is $118 / 35=3.3714$. The percentage of value is 3.3714 / $4 \times 100=84.3 \%$.

g. Analysis of the first question, from the table above it can be seen that the total value of 35 respondents for the seventh question is 119 . The average score is $119 / 35=3.4$. The percentage of value is $3.4 / 4 \times 100=85 \%$.

h. Analysis of the first question, from the table above it can be seen that the total value of 35 respondents for the eighth question is 120 . The average score is $120 / 35=3.4285$. the percentage value is $3.4285 / 4 \times 100=85.7 \%$.

i. Analysis of the first question, from the table above it can be seen that the total value of 35 respondents for the ninth question is 118 . The average score is $118 / 35=3.3714$. The percentage of value is 3.3714 / $4 \times 100=84.3 \%$.

j. Analysis of the first question, from the table above it can be seen that the total value of 35 respondents for the tenth question is 96 . The average score is $96 / 35=2.7428$. The percentage is $2.7428 / 4 \times 100=68.5 \%$.

The summary results of the overall media utilization analysis can be seen in Table 5 .

Table 5. Analysis of Results

\begin{tabular}{|c|c|c|c|c|}
\hline \multirow[t]{2}{*}{ Question } & \multicolumn{4}{|c|}{ Score } \\
\hline & Qty & Qty / Resp. & $\%$ & AVG \\
\hline \multicolumn{5}{|c|}{ System Aspects } \\
\hline 1 & 140 & 4 & $100 \%$ & \multirow{3}{*}{$88.3 \%$} \\
\hline 2 & 111 & 3.1714 & $79.3 \%$ & \\
\hline 3 & 120 & 3,4285 & $85.7 \%$ & \\
\hline \multicolumn{5}{|c|}{ User Aspects } \\
\hline 1 & 131 & 3,7428 & $93.5 \%$ & \multirow{6}{*}{$85.8 \%$} \\
\hline 2 & 115 & 3.2875 & $82.1 \%$ & \\
\hline 3 & 118 & 3.3714 & $84.3 \%$ & \\
\hline 4 & 119 & 3.4 & $85 \%$ & \\
\hline 5 & 120 & 3,4285 & $85.7 \%$ & \\
\hline 6 & 118 & 3.3714 & $84.3 \%$ & \\
\hline \multicolumn{5}{|c|}{ Interaction Aspects } \\
\hline 1 & 96 & 2.7428 & $68.5 \%$ & $68.5 \%$ \\
\hline
\end{tabular}




\section{Conclusion}

Based on the research carried out, an average of $88.3 \%$ for System Aspects stated that they agree that the Telegram display is easy to use, the button feature makes searching easier, and voice media can make it easier to pronounce prayers or sloka.

In the User Aspect, it is known that an average of $85.8 \%$ agrees that chatbots can be a means of accessing prayers or sloka, chatbots make it easier to search, chatbots are more practical than other media, chatbots can replace other media in accessing prayers or sloka, delivering prayers or quick sloka delivered, and the chatbot deserves to provide information about hindu sloka or prayer.

In the Interaction Aspect, it is known that the average is $68.5 \%$, agreeing that the suggestion feature can provide convenience if users want to provide suggestions for the prayer in question.

In the System and User Aspects it has exceeded $80 \%$ while for the Interaction Aspect it is less than $80 \%$. For this reason, it is necessary to improve the Interaction Aspect. The Interaction aspect contains the suggestion feature available on the Telegram chatbot, for that it is necessary to make improvements to the suggestion feature so that this feature can be more easily used by users.

Making a Telegram chat bot which is implemented as a medium used to find prayer and prayer information. The Telegram chat bot that is made to be able to provide information services about prayers and prayer, can also be used by the admin to manage prayer and prayer data on a website that is connected to the Telegram chat bot. The ability of the bot to process updates is affected by the internet speed of the PC Server.

\section{References}

[1] Abhisena, I. A., Sukarsa, I., \& Githa, D. (2017). Implementation of Database Auditing by Utilizing DBMS Synchronization. Lontar Computer Journal, 89-100.

[2] Andrean, J. (2019, December 24). Understanding Sloka in Hinduism. Taken back from DORIPOS: https://doripos.com/pengentuk-sloka-dalam-agama-hindu

[3] Anhar. (2010). Guide to Mastering PHP \& MySQL by Self-Teaching. Jakarta: Our Media.

[4] Ariasih, N., \& Sri Artha, I. (2017). E-Complaint STIKIClass Facilities Design. Lontar Computer Journal, 101-111.

[5] Bali, G. (2016, June 26). The Bhagavad Gita Book. Taken back from GamaBali: http://gamabali.com/ Bible-bhagawad-gita/

[6] Dianing. (2012). Proficient in PHP and MySQL. Jakarta: Kuncikom.

[7] Do, T. T., \& Gatica-Perez, D. (2011). Human Interaction Discovery in Smartphone Proximity Networks. Proceedings of the International Symposium on Wearable Computers.

[8] Dunlop, M., \& Brewster, S. (2002). The Challenge of Mobile Devices for Human Computer Interaction. Personal and Ubiquitous Computing, 235-236.

[9] Firman, A., Wowor, H., \& Najoan, X. (2016). Web-Based Online Library Information System. E-journal of Electrical and Computer Engineering, 29-36.

[10] Hamburger, E. (2014, Feb 25). Why Telegram has become the hottest messaging app in the world. Retrieved from TheVerge: https://www.theverge.com/2014/2/25/5445864/telegrammessenger-hottest-app-in-the-world

[11] Hamsah, U. (2003). Ethical Concepts in Bhagavadgita. Journal of Philosophy, 271-278.

[12] Hasan, B. (2016). Make Your Own TELEGRAM BOT from PHP. Indonesia: Indonesian Digital Teacher.

[13] I. N. S. Paliwahet, I. M. Sukarsa, and I. K. Gede Darma Putra, "Searching for Bali Regional Tourism Information Using Chatbot Technology," Lontar Komput. J. Ilm. Technol. Inf., Vol. 8, no. 3, p. 144, 2017, doi: 10.24843 / Ikjiti.2017.v08.i03.p01. 
[14]Laisina, L., Haurissa, M., \& Hatala, Z. (2018). GPM GIDION WAIYARI AMBON CONGREGATION DATA INFORMATION SYSTEM. SIMETRIC JOURNAL, 139-144.

[15] Mediana, D., \& Nurhidayat, A. I. (2018). DESIGN AND BUILD THE WEB-BASED HELPDESK (A-DESK) APPLICATION USING. Journal of Informatics Management, 75-81.

[16]Musiafa, Z. (2019). Build Multi Store Inventory Application with Visual Basic and MySQL. Banjarmasin: The Islamic University of Kalimantan Muhammad Arsyad Al Banjari.

[17] Netra, A. A. (2009). Basic Guidelines for Hinduism. Denpasar: Widya Dharma.

[18] Niwaksara, T. (2019). Hindu Daily Prayers. Denpasar: ESBE Books.

[19] Nova, S. P. (2018). EFFECTIVENESS OF TELEGRAM APPLICATION COMMUNICATIONS AS. JOM FISIP, 1-11.

[20] Nusufula, R., \& Susanto, A. (2018). Designing a Chat Bot on a Credit Server Using the Telegram Bot API. Journal of Information Systems, 80-88.

[21] Permana, B. (2013). Fast Advanced Programming Language Fast Advanced Programming Language. Bandung: eLearning IlmuKomputer.Com Community.

[22] Pinto, R. L. (2014). Secure Instant Messaging. Department of Computer Science and Engineering, Frankfurt University, 19-20.

[23] Putra, K. (2014). WEDA AS THE SOURCE OF HINDU RELIGIOUS TEACHING. Taken back from Blogger Bali: https://www.komangputra.com/weda.html

[24]R. Agustina and D. Suprianto, "Analysis of the Results of Using Logical Algebra Interactive Learning Media with User Acceptance Test (UAT)," Smatika J., vol. 8, no. 02, pp. 67-73, 2018, doi: 10.32664 / smatika.v8i02.205

[25] Sastrawangsa, G. (2017). Use of Telegram Bot to Automate Student Information and Services in the Smart Campus Concept. 2017 National Conference on Systems \& Informatics, 772-776.

[26] Standsyah, R. E., \& Restu N.S, I. S. (2017). PHPMYADMIN IMPLEMENTATION IN. UJMC Journal, 38-44.

[27] Suasanti, S., Junianto, E., \& Rachman, R. (2017). Implementation of Laravel Framework in Web-Based Academic Value Processing Applications. INFORMATICS Journal, 108-117.

[28] Sukarsa, I., Darma Putra, I., Sastra, N., \& Jasa, L. (2018). Modification of ISONER Framework as Enterprise Service Bus to Build Consultation Robot Using External Engine. International Journal of Engineering and Emerging Technology, 123-128.

[29] Swami Prabhupada, S. A. (1989). Bhagavad Gita According to the Origin. Hanuman Sakti.

[30] Swastika, I. K. (t.y.). Nitya Karma Puja Daily Prayers of Hindus. Badung: Taman Beji Sari Ashram.

[31] Taylor, A. G. (2003). SQL For Dummies, 5th Edition. Canada: Wiley Publishing.

[32] Teguh Wirawan, K., Sukarsa, I., \& Agung Bayupati, I. (2019). Balinese Historian Chatbot using Full-Text Search and Artificial Intelligence Markup Language Method. I.J. Intelligent Systems and Applications, 21-34.

[33] Telegram. (t.y.). Telegram FAQ. Retrieved from Telegram: https://telegram.org/faq\#q-whatis-telegram-what-do-i-do-here

[34] Yudanto, A. L., Tolle, H., \& Brata, A. H. (2017). Application Design of Management Information System of Biomedical Laboratory, Faculty of Medicine, Universitas Brawijaya. Journal of Information Technology Development and Computer Science, 628-634.

[35] Zuliarso, E., \& Februariyanti, H. (2013). Use of Instant Messaging for Academic Service Applications. Journal of DYNAMIC Information Technology, 112-121. 